\title{
ZMIANY W PROCEDURZE BADANIA WIARYGODNOŚCI KREDYTOBIORCÓW
}

\author{
Aurelia Bielawska \\ Uniwersytet Szczeciński
}

\begin{abstract}
Abstrakt. Celem artykułu jest przedstawienie zmian w procedurze badania wiarygodności kredytobiorców, których całkowite wdrożenie przewidywane jest do 2019 roku i rekomendowanie przedsiębiorstwom podjęcia działań, dzięki którym mogą umożliwić sobie trwały rozwój i jednocześnie pozytywnie wpłynąć na swoją notę ratingową. Wysoka nota ratingowa otrzymana według kryterium Bazylea III może zapewnić przedsiębiorstwu korzystne warunki kredytowania i zmniejszenie kosztów finansowania działalności. Artykuł został napisany na podstawie studiów obowiązujących aktów prawnych, literatury przedmiotu i polityki zarządzania ryzykiem $\mathrm{w}$ banku.
\end{abstract}

Słowa kluczowe: Bazylea III, kredyt bankowy, rating finansowy, rating strukturalny

\section{WSTĘP}

Regulacje bankowe określane jako Bazylea III mają na celu przede wszystkim wzmocnienie odporności systemu finansowego na wypadek materializacji ryzyka systemowego i wspieranie przez to długookresowego, zrównoważonego wzrostu gospodarczego kraju ${ }^{1}$. Nowe reguły bankowe oddziałują na warunki dostępu do kredytów bankowych wszystkich przedsiębiorstw w krajach UE, jednakże ze względu na swoją specyfikę MŚP mogą zostać dotknięte tymi zmianami w większym stopniu niż duże przedsiębiorstwa.

\footnotetext{
${ }^{1}$ Ustawa z dnia 5 sierpnia 2015 r. o nadzorze makroostrożnościowym nad systemem finansowym i zarządzaniu kryzysowym w systemie finansowym (Dz.U. 2015 poz. 1513, art. 1).
} 


\section{CO ZMIENIAJĄ NOWE REGUŁY BANKOWE ?}

Nowe reguły adekwatności kapitałowej zmuszają banki do zwiększenia ilości i jakości kapitału własnego zabezpieczającego udzielone kredyty, tak aby w razie sytuacji kryzysowej banki mogły same się refinansować. Nowe reguły bankowe mogą spowodować zwiększenie kosztów kredytowania, a ponadto może ulec zmniejszeniu wolumen udzielanych kredytów [Hofbauer, Kral i Seiler 2015] Restrykcyjne przepisy dotyczące zabezpieczenia aktywów ważonych ryzykiem (RWA) wynikające z Bazylei III powodują, że banki preferują przedsiębiorstwa z większymi szansami przetrwania, mniej ryzykowne i w związku z tym przedsiębiorstwo starając się o kredyt powinno przekonać bank o swoich dobrych perspektywach rynkowych. Do identyfikacji dobrze zarządzanego przedsiębiorstwa tradycyjnie stosowane mierniki zorientowane na informacje pochodzące z rocznych sprawozdań finansowych to za mało. W związku z tym banki sporządzają nie tylko rating finansowy, ale również rating strukturalny [Hofbauer i Bergmann 2016].

Efektywne zarządzanie przedsiębiorstwem wynika z dążenia założycieli przedsiębiorstwa do osiągnięcia zamierzonych celów. Wysoka nota ratingowa może być dodatkowym efektem tych starań i może przyczynić się nie tylko do uzyskania lepszych warunków kredytowania, ale również do wzrostu wartości rynkowej ocenianego przedsiębiorstwa.

Przedmiotem ratingu są zarówno cechy ilościowe, jak i jakościowe przedsiębiorstwa ubiegającego się o kredyt, dlatego przedsiębiorstwo oprócz dokumentów finansowych wraz z wnioskiem kredytowym powinno dostarczyć dokumenty umożliwiające sporządzenie ratingu strukturalnego.

\section{POZYSKIWANIE FINANSOWANIA BĘDZIE TRUDNIEJSZE}

Normy ostrożnościowe zawarte w Bazylei III stanowią w znacznym stopniu modyfikację i kontynuację rozwiązań przedstawionych w umowie bankowej z 1988 roku określanej mianem Bazylea I. Uregulowania te ustanowiły, dla banków prowadzących działalność międzynarodową, minimalną wartość wskaźnika BIS - informującego o relacji funduszy własnych banku do aktywów ważonych ryzykiem (RWA) w wysokości co najmniej 8\%. Wskaźnik BIS ulegał podwyższeniu lub obniżeniu w sposób standardowy w zależności od klasy ratingu do jakiej zaliczony został kredytobiorca. Oznaczało to, że banki dla każdego kredytu ważonego ryzykiem zobowiązane zostały do utworzenia na kapitale własnym rezerwy w odpowiedniej wysokości. Dopuszczalny rozmiar akcji kredytowej banku uzależniony został więc od wartości posiadanego kapitału. 
Szybko jednak okazało się, że przyjęte ograniczenia nie wystarczą, aby zapobiec pojawieniu się kolejnego kryzysu finansowego. Głównym powodem był fakt, że sposób obliczania wartości RWA nie uwzględniał wszystkich rodzajów ryzyka bankowego, jakie pojawiły się m.in. wraz ze wzrostem znaczenia instrumentów pochodnych na rynkach finansowych.

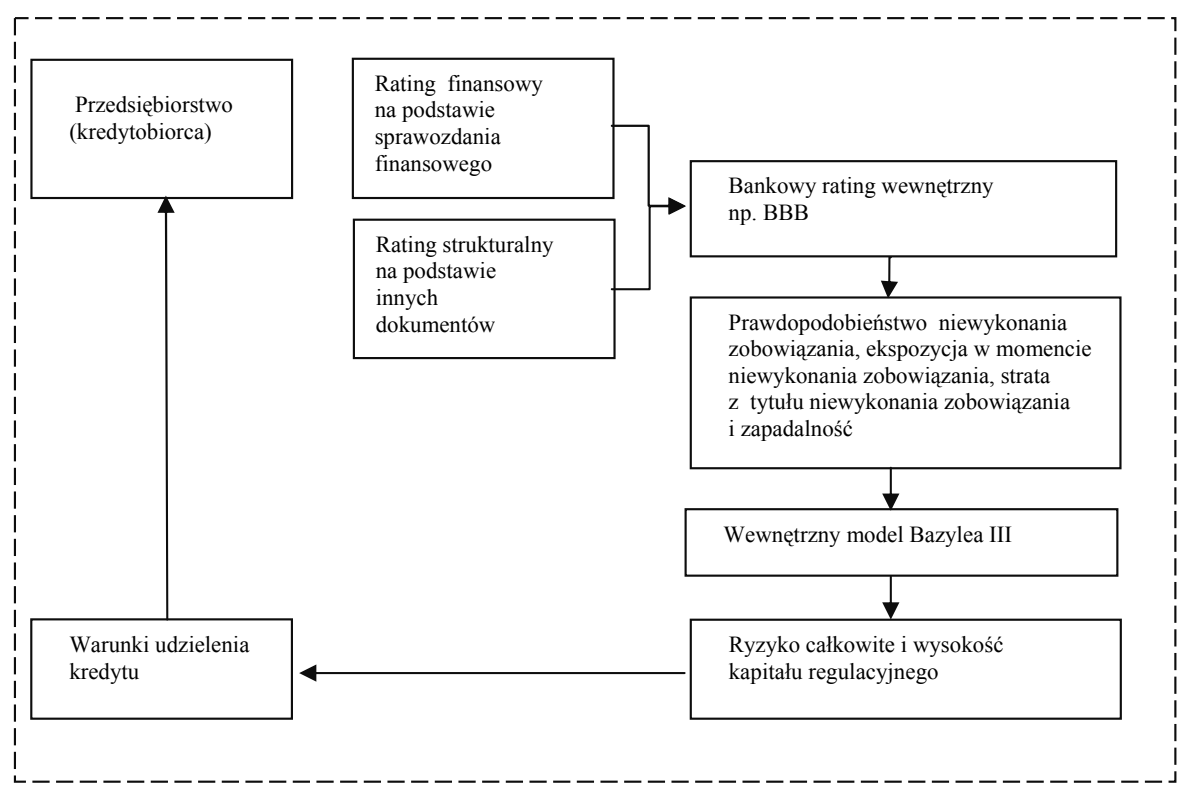

RYSUNEK 1. Rating finansowy i rating strukturalny jako składniki procedury udzielania kredytu

Źródło: Opracowanie własne na podstawie studiów literaturowych.

Główna idea Bazylei I dotycząca utrzymywania przez bank minimalnej wartości wskaźnika BIS na poziomie $8 \%$ została utrzymana również w nowej umowie bankowej obowiązującej od 1 stycznia 2007 roku. Modyfikacji poddano dotychczasowe metody wyznaczania kapitału banku czyli wymogu kapitałowego dla pokrycia ryzyka kredytowego. Niestety znowelizowanie reguł i ich wdrożenie nie zapobiegło wystąpieniu kolejnego kryzysu finansowego. Wyniki analiz Banku Rozrachunków Międzynarodowych wykazały, że straty poniesione przez 99\% tzw. banków światowych w czasie kryzysu zapoczątkowanego w 2007 roku wyniosły 5 lub mniej procent wartości RWA [Langer, Eschenburg i Eschbach 2013]. Czyli straty były mniejsze niż minimalna wartość wskaźnika BIS wymagana przez normy bankowe. W związku z tym poniesione straty nie mogły doprowadzić do niestabilności systemu finansowego. Okazało się więc, że definicje kapitału banku przyjęte w Bazylei I i Bazylei II były nieprecyzyjne, a kapitał banku charakteryzował się ograniczoną zdolnością absorpcji strat i nie mógł pokryć powstałych 
niedoborów. W odpowiedzi na zaistniałą sytuację BCBS przygotował i opublikował w grudniu 2009 roku pierwsze dokumenty dotyczące kolejnych zmian reguł bankowych, które we wrześniu następnego roku opublikowane zostały jako Bazylea III. Równolegle do prac Komitetu Bazylejskiego ds. Nadzoru Bankowego w Unii Europejskiej trwały prace nad regulacjami (pakiet CRD IV/CRR) umożliwiającymi transpozycję do prawa unijnego znowelizowanych reguł ostrożnościowych ${ }^{2}$. Do najważniejszych zmian, należy zaliczyć nowy sposób obliczania kapitału regulacyjnego banku, tak by kapitał ten był w stanie zapewnić rzeczywistą absorpcję strat.

\begin{tabular}{|c|c|c|}
\hline \multicolumn{3}{|c|}{ BAZYLEA II „dzisiaj” } \\
\hline $\begin{array}{c}\text { Kapitał podstawowy } \\
2 \%\end{array}$ & $\begin{array}{c}\text { Kapitał uzupełniający I klasy } \\
2 \%\end{array}$ & $\begin{array}{c}\text { Kapitał uzupełniający II klasy } \\
4 \%\end{array}$ \\
\hline
\end{tabular}

Wskaźnik funduszy własnych do aktywów ważonych ryzykiem 8 \%.

BAZYLEA III (wartości docelowe 2019)

\begin{tabular}{|c|c|c|c|c|}
\hline Współczynnik & Dodatkowy & Kapitał & Bufor & Bufor \\
kapitału & kapitał & uzupełniający & zabezpieczający & antycykliczny \\
podstawowego & podstawowy & $2,0 \%$ & $2,5 \%$ & $0-2,5 \%$ \\
$4,5 \%$ (Tier I) & $1,5 \%$ & (Tier II) & & \\
\hline
\end{tabular}

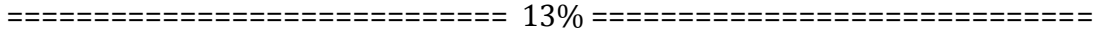

Wskaźnik funduszy własnych do aktywów ważonych ryzykiem $13 \%$

RYSUNEK 2. Wymagania dotyczące kapitału regulacyjnego według Bazylei II oraz Bazylei III Źródło: Zarządzenie nr 5/98 Komisji Nadzoru Bankowego, Rozporządzenie Parlamentu Europejskiego i Rady (UE) nr 575/2013.

Umowa Bazylea III wprowadziła ujednolicone w skali międzynarodowej uregulowania dotyczące płynności banków. Zarządzenie Komisji Nadzoru Finansowego (KNF) w sprawie sposobu wyliczenia współczynników CRR wypłacalności banku oraz procentowych wag ryzyka przypisanych poszczególnym kategoriom aktywów i zobowiązań pozabilansowych, nakazuje bankom dysponować taką ilością kapitału (kapitału regulacyjnego) ${ }^{3}$, która pozwoli im pokryć nieoczekiwane straty i zachować wypłacalność w każdej sytuacji, także w razie kryzysu. Z powyższego wynika, że wartość kredytów udzielonych przez bank zależy od ryzyka tych kredytów. Ponadto Bazylea III nakłada na banki obowiązek tworzenia

\footnotetext{
${ }^{2}$ W dniu 27 czerwca 2013 r. w Dzienniku Urzędowym Unii Europejskiej został opublikowany finalny tekst tzw. pakietu CRD IV/CRR w wersji polskiej.

${ }^{3}$ Kapitał regulacyjny (RC) jest to prawny środek ostrożnościowy zdefiniowany przez regulatora i służący jako minimalna kwota Tier 1. i Tier 2., a także kapitał zapasowy wymagany do absorpcji nieoczekiwanych strat. Minimalna wartość kapitału to RC, którą bank musi utrzymywać z perspektywy regulacyjnej w funkcji amortyzatora umożliwiającego przetrwanie w przypadku dużych nieoczekiwanych strat.
} 
dwóch kapitałowych buforów bezpieczeństwa: (1) buforu zabezpieczającego oraz (2) buforu antycyklicznego. Wymogi płynnościowe to kolejne narzędzie ostrożnościowe wprowadzone nowymi regulacjami. Wpływ tych regulacji na możliwości kredytowania zależy od klas aktywów jakie zaliczone zostaną do najbardziej płynnych. Restrykcyjne zasady w tym zakresie mogą spowodować, że regulacje te będą znacznie bardziej kosztowne dla banków i gospodarki niż wymóg utrzymywania większego kapitału. Szczególnie niekorzystne dla polskiego sektora bankowego jest przewidziane dyrektywą podejście grupowe w odniesieniu do możliwości tworzenia grup płynnościowych, których elementem stałyby się banki zależne od podmiotów zagranicznych [Bielawska 2016].

Bazylea III wprowadziła górną granicę zadłużenia tzw. dźwignię finansową - nominalna suma wszystkich aktywów banku nie powinna (w przyszłości) przekroczyć 33-krotnej wartości kapitału własnego. Banki są zobowiązane już od 2011 roku do ustalania kapitału własnego według nowych zasad i do zrewidowania wag ryzyka oraz dostosowania ich do aktualnego zakresu działalności. Może to nastąpić w drodze zwiększenia kapitału, alokacji zysku do rezerw lub ograniczenia akcji kredytowej.

W aktywach bilansu banku wykazywane są należności od kredytobiorców np. kredyty, po stronie pasywów natomiast wykazywane są kapitał własny i rezerwy. Wymagania dotyczące kapitału własnego odnoszące się do ekspozycji banku na ryzyko w decydującym stopniu zależą od wiarygodności kredytowej dłużnika (jakości aktywów). Banki, dążąc do zrealizowania zaleceń wynikających z reguł bankowych udzielając kredyty zmuszone są uwzględniać różnice w zakresie ryzyka kredytowego należności od poszczególnych dłużników. Zadanie to spełniają ratingi.

W tabeli 1 zestawiono wskaźniki informujące o procentowym udziale rezerw na kapitale własnym, tworzonych w zależności od ratingu finansowanych podmiotów. Z danych zawartych w tabeli wynika, że transakcje kredytowe o wyższym poziomie ryzyka wymagają zaangażowania większych funduszy banku niż finansowanie projektów o mniejszym ryzyku. Banki zatem będą żądały większej zapłaty za kredyty udzielane klientom o „gorszym” ratingu.

Wskaźniki przedstawione w tabeli wskazują, że nowe wymogi ostrożnościowe odnośnie do kapitału regulacyjnego banku wymagają większego zaopatrzenia banków w kapitał, w przeciwnym razie zmniejszą się możliwości banków w zakresie udzielania kredytu. Większe wymagania dotyczące kapitału banków prowadzą do zmniejszenia wolumenu kredytów przy jednoczesnym faworyzowaniu kredytów o niskim poziomie ryzyka. Przede wszystkim przedsiębiorstwa z niskim ratingiem muszą uwzględniać możliwość znaczącej podwyżki odsetek od kredytów. Zróżnicowanie wymaganej minimalnej ilości funduszy banku w zależności od ratingu udzielanych kredytów powoduje powstawanie dodatkowych kosztów banku. Kosztami tymi zostaną obciążeni klienci banku, a to oznacza, że przedsiębiorstwa z niższymi ocenami ratingowymi muszą liczyć się ze wzrostem kosztów kredytowania. 
TABELA 1. Wskaźniki rezerwy na kapitale banku zależne od ryzyka kredytu (\%)

\begin{tabular}{|c|c|c|c|c|c|c|}
\hline Rating & $\begin{array}{c}\text { AAA } \\
\text { do AA- }\end{array}$ & $A+$ do $A-$ & $\begin{array}{c}\mathrm{BBB}+ \\
\text { do BBB- }\end{array}$ & $\begin{array}{c}\mathrm{BB}+ \\
\text { do BB- }\end{array}$ & Poniżej B- & Bez ratingu \\
\hline Kraju & 0 & 20 & 50 & 100 & 150 & 100 \\
\hline Wiarygodność kraju & 20 & 50 & 100 & 100 & 150 & 100 \\
\hline Wiarygodność banku & 20 & 50 & 50 & 100 & 150 & 50 \\
\hline $\begin{array}{l}\text { Zadłużenie } \\
\text { krótkoterminowe }\end{array}$ & 20 & 20 & 20 & 50 & 150 & 20 \\
\hline Przedsiębiorstwa & 20 & 50 & \multicolumn{2}{|c|}{100} & 150 & $(\geq) 100$ \\
\hline \multicolumn{7}{|c|}{$\begin{array}{lr}\text { Pozostałe aktywa : } & \\
\text { Kredyty hipoteczne dla klientów indywidualnych } & 35 \\
\text { Komercyjne kredyty hipoteczne } & 100 \\
\text { Pożyczki osobiste } & 100 \\
\text { Venture Capital w zależności od decyzji krajowego nadzoru bankowego }\end{array}$} \\
\hline
\end{tabular}

Źródło: Opracowanie własne na podstawie Wilkens M., Völker O., [2001], Rozporządzenie Parlamentu Europejskiego i Rady Europy (UE) nr 575/2013.

\section{UDOSTĘPNIAĆ WIĘCEJ NIŻ TYLKO LICZBY}

Dotychczas analizowanie przez banki wiarygodności kredytowej kredytobiorców koncentrowało się przede wszystkim na badaniu wskaźników finansowych (rating finansowy). Po implementacji w systemie bankowym umowy Bazylea III pojawiło się żądanie dokonywania dodatkowo oceny przedsiębiorstwa ze względu na aspekt przyszłej zdolności płatniczej co pozwala ocenić szanse dalszego istnienia przedsiębiorstwa (rating strukturalny). Analiza wskaźników finansowych opisujących sytuację finansową przedsiębiorstwa jest zorientowana w znacznym stopniu na przeszłość, tymczasem kredyt będzie spłacony w przyszłości i w związku z tym banki zainteresowane są trwałością istnienia przedsiębiorstwa.

Trwałość istnienia przedsiębiorstwa można analizować stosując tzw. rating strukturalny [Hofbauer i Bergmann 2008]. Zadaniem ratingu strukturalnego jest ocena aktualnej sytuacji przedsiębiorstwa na rynku i ocena zdolności przedsiębiorstwa do osiągania sukcesów w przyszłości. Na ocenę zdolności przedsiębiorstwa do osiągania sukcesów w przyszłości wpływa zarówno sytuacja finansowa przedsiębiorstwa, jego otoczenie, rodzaj prowadzonej działalności, sposób zarządzania przedsiębiorstwem, personel (pracownicy i osoby zarządzające), jak również stosowane instrumenty kontrolingu, planowania, a nawet marketingu. Przeprowadzenie takiej oceny przez instytucję finansującą pozwala ocenić szan- 
se powodzenia przedsiębiorstwa, wymaga jednak wielu informacji o zarządzaniu przedsiębiorstwem i o jego wewnętrznej strukturze. Istotnym czynnikiem przyczyniającym się do osiągnięcia sukcesu jest pozycja konkurencyjna przedsiębiorstwa na rynku. Dalszymi istotnymi czynnikami sukcesu są perspektywy na przyszłość i jakość zarządzania. W dobrze zarządzanym przedsiębiorstwie sporządzane są, nie tylko plany działalności, ale również opracowywana jest strategia działania i kontroli. Wyniki tych opracowań znane są pracownikom przedsiębiorstwa, są przez nich akceptowane i stosowane w przedsiębiorstwie w sposób przyczyniający się do jego rozwoju.

\section{PODSUMOWANIE}

Przedstawione rozważania wskazują, że w najbliższej przyszłości przedsiębiorstwa będą musiały ponieść więcej trudu, aby uzyskać finansowanie z banku. Nowe wymogi nadzoru bankowego Bazylea III zobowiązują banki do jeszcze większego uzależnienia finansowania przedsiębiorstw od ich wiarygodności. Banki uzależniają warunki (koszty) kredytowania nie tylko od aktualnej sytuacji finansowej przedsiębiorstwa, ale również zwracają uwagę na zdolność płatniczą przedsiębiorstwa jaka może wystąpić $\mathrm{w}$ najbliższym czasie. W związku z tym ważne są rodzaj i jakość dokumentów, które zostają udostępnione. Banki potrzebują aktualnych informacji, obszerniejszych niż dane uzyskiwane ze sprawozdawczości finansowej. Oczekują udokumentowanych informacji, które pozwolą ocenić szanse powodzenia przedsiębiorstwa $\mathrm{w}$ najbliższych latach. Procedury bankowe wynikające z implementacji reguł Bazylei III wskazują jednoznacznie, że obecnie większe znaczenie, niż dotychczas, mają czynniki jakościowe oddziałujące na ryzyko i sukces finansowanego projektu. Bank w procesie ratingu wykorzystuje różne dokumenty dostarczone przez przedsiębiorstwo, w szczególności plany strategiczne, plany marketingowe, dane dotyczące pozycji rynkowej, jakości zarządzania i tworzenia wartości rynkowej, dokumentację przedstawiającą wszystkie ważne czynniki oddziałujące na działalność przedsiębiorstwa. Badania prowadzone w bankach wskazują, że korzystny wpływ na ocenę wiarygodności kredytobiorcy ma dostarczenie bankowi odpowiednich dokumentów wraz z wnioskiem kredytowym. Późniejsze ich dostarczenie może zostać odebrane jako chęć ukrycia istotnych informacji.

Opracowanie strategii rozwoju $\mathrm{w}$ formie papierowej i przedstawienie jej w banku wraz z wnioskiem kredytowym może w znaczący sposób wpłynąć na rating. Im więcej informacji o sobie dostarczy przedsiębiorstwo, tym większa szansa na otrzymanie kredytu i na korzystniejsze warunki kredytowania. 
Decyzją Bazylejskiego Komitetu Bankowego od 2011 roku następuje stopniowe wdrażania do systemu bankowego krajów Unii Europejskiej norm ostrożnościowych określanych jako Bazylea III. Nowe reguły nakładają na banki obowiązek posiadania kapitałów własnych większej wartości i wyższej jakości. Wartość kapitałów, które będą musiały utrzymywać banki zależy od ryzyka finansowanych projektów. W związku z tym kredyty udzielone na finansowanie bardziej ryzykownych projektów będą droższe. Przedsiębiorstwa mają możliwość obniżenia ryzyka swojego projektu dostarczając bankowi, wraz z wnioskiem kredytowym, obszerne informacje o tym projekcie.

\title{
Spis literatury
}

BIELAWSKA A., 2016: Bazylea III i kredyty bankowe dla MŚP, [w:] Marketing i Zarządzanie, 2 (43), s. 259-271.

HOFBAUER, G. KRAL M., SEILER P., 2015: Evidenzbasiertes Rating von Unternehmen und der Einfluss von Marketing und Vertrieb im Lichte von Basel III. Working Paper Heft, Nr. 33, Technische Hochschule Ingolstadt.

HOFBAUER G., BERGMANN S., 2016: Optimales Rating für KMU So überzeugen Sie Ihre Bank, PUBLICIS Technische Hochschule Ingolstadt.

LANGER C., ESCHENBURG K., ESCHBACH E., 2013: Rating und Finanzierung im Mittelstand Letfaden für erfolgreiche Banbkgespräche.

Rozporządzenie Parlamentu Europejskiego i Rady (UE) nr 575/2013 z dnia 26 czerwca 2013 r. w sprawie wymogów ostrożnościowych dla instytucji kredytowych i firm inwestycyjnych.

WILKENS H., VÖLKER O., 2001: Strukturen und Methoden von Basel II - Grundelgende Veränderungen der Bankaufsicht, [w:] „Zeitschrift für das gesamte Kreditwesen”, nr 4.

Zarządzenie nr 5/98 Komisji Nadzoru Bankowego z dnia 2 grudnia 1998 r. w sprawie sposobu wyliczenia współczynnika wypłacalności banku oraz procentowycy wag ryzyka przypisanych poszczególnym kategoriom aktywów i zobowiązań pozabilansowych.

\section{CHANGES IN PROCEDURES STUDY OF THE ENTERPRISES CREDIBILITY}

\begin{abstract}
The article discusses the new Basel III banking rules, which increase the requirements for banks, by the necessity of holding equities of higher value and quality. Capital requirements, which relate to the bank's risk exposure depend to the highest degree on the creditworthiness of the debtor (asset quality). So far, the analysis of the creditworthiness of borrowers, focused primarily on the study of financial indicators. After the implementation of Basel III there was a request to make an additional - qualitative - assessment of business, due to the future sol-
\end{abstract}


vency perspectives. Therefore, these loans, which finance riskier projects, become more expensive. Enterprises, wishing the reduction of the cost of credit, should - together with the loan application - provide an extensive information about their current and future activities to the bank.

Key words: Bazylea III, bank credit, financial rating, structured rating 